\title{
Problems and Methods of Diagnosis of Respiratory Viral Infections of Birds
}

\author{
Khripko YUI ${ }^{1,2}$, Shatokhin $\mathrm{KS}^{2}$ and Blazhko NV ${ }^{2 *}$ \\ ${ }^{1}$ FBUN SSC VB “Vector" Rospotrebnadzor, Russia \\ ${ }^{2}$ Novosibirsk GAU, Russia
}

Submission: January 20, 2019 ; Published: January 30, 2019

*Corresponding author: Blazhko NV, FBUN SSC VB "Vector” Rospotrebnadzor, Russia

\section{Mini Review}

Viruses, according to the latest ideas [1,2], are the oldest creatures on our planet, possessing greater genetic diversity than any of the cellular organisms [3]. Unfortunately, viruses from free-living replicating elements evolved into parasites that embed their genetic material into the nucleotide sequence of the carrier. Naturally, any alien genetic material is perceived by the body of an infected creature as a threat, prompting, in turn, the response of the immune system [4]. The consequences of this response, such as fever, tumor and cell apoptosis, are quite painful processes that sometimes lead to the death of the host organism [5]. Since many viruses are characterized by a mode of transmission between individuals of the host species, or even interspecific transmission, viral diseases often become epidemics. Since the external symptoms of various viral diseases are quite like each other, animal husbandry in general and poultry farming constantly need to improve old ones and develop new methods for diagnosing viral diseases $[6,7]$. The purpose of this review is to briefly describe the current methods for diagnosing avian influenza virus and Newcastle disease, some of the most dangerous and common infections of birds $[8,9]$.

Direct immunofluorescence (DFA) is used to detect a variety of viruses, including influenza viruses and NDV. Direct immunofluorescence analysis takes from 2 to 3 hours. Direct immunofluorescence for detection of influenza A virus has a sensitivity from 70 to $100 \%$, specificity 80 to $100 \%$, PPV 85-94\%, NPV 96-100\% [10]. The combination of direct immunofluorescence with a virus culture yields about 5-15\% more positive results than the immunofluorescence itself $[11,12]$.

Enzyme-linked immunosorbent assay (ELISA). Many Influenza A and B ELISA kits have been introduced in the last 10 years [13-16]. This method has a sensitivity of 70 to $75 \%$, which is significantly lower than that of virus cultures and direct immunofluorescence but has a good specificity of 90-95\%. Due to the low sensitivity of these tests, false negative results are a major problem, and PPV will decrease as the infection spreads. In addition, these test systems should be subject to internal evaluation, and their work should be evaluated every season in connection with the change of circulating strains. However, for the diagnosis of avian influenza viruses, a few commercial test systems based on rapid ELISA have been developed $[9,13,17]$.

PCR analysis. The most progressive and accurate method for the diagnosis of viral infections [18,19]. There are several variations of this method. Non-specific detection methods based on the binding of double-stranded DNA to intercalating dyes such as ethidium bromide, YO-PRO-1 [20] and SYBR-green1 [21]. HybProbes. The method is based on probes (primers) from the 3 ' end is labeled with a donor fluorophore (FITC), the second is labeled at the 5 ' end with a fluorophore acceptor, so that when both oligonucleotides are located on the DNA chain, the two fluorophores are 10 the friend and luminescence of the acceptor fluorophore is enhanced [22,23]. Molecular beacon. The technology is based on probes that form hairpins, which at the ends are labeled with a fluorophore and a quencher $[24,25]$. TaqMan. The amplicon was detected as a result of the 5 ' $\rightarrow$ ' endonuclease activity of the Taq DNA polymerase that cleaved the probe and facilitated cleavage of the fluorophore and quencher from the probe $[26,27]$. RT-PCR, or reverse transcription, is based on the use of virus-specific oligonucleotide primers or random hexamers. It is considered a rather effective way to diagnose viruses [28].

Unfortunately, despite the progression of PCR analysis, today in Russia, foreign test systems are mainly used to identify avian influenza viruses and Newcastle disease. From domestic developments, only a multiplex PCR test system developed by the Vector State Research Institute of Physics and Technology [29] can be considered a truly effective method. Its advantages include the $100 \%$ accuracy of identifying individual strains of influenza viruses, as well as the virus of Newcastle disease, and the joint testing of standard virus strains from the collection of the Vector did not affect the accuracy of the analysis Ilinykh [29]. However, even though the development has successfully passed production testing in several laboratories in Siberia and Kazakhstan, it remains unclaimed. The low demand for 
this analytical method creates the need for an active marketing campaign, which is the goal of our future work.

\section{References}

1. Markov A (2018) The birth of complexity. Evolutionary biology today: unexpected discoveries and new questions. publishing house Act Corpus, Moscow, Russia, pp. 528.

2. Moelling K (2016) Viruses: More Friends Than Foes. University of Zurich, Switzerland \& Max Planck Institute for Molecular Genetics, Berlin, Germany, pp. 420

3. Lewin B, Genes IX (2008) Jones \& Bartlett Learning. pp. 892.

4. Boyd WC (1966) Fundamentals of immunology. ( $4^{\text {th }}$ edn), New York, London, Sydney, pp. 647.

5. Agol VI (2015) Nature of virus pathogenicity. Nature, 5: 3-10.

6. Veterinary encyclopedia (2013) Under the General editorship of AI Yatusevich 2: 596.

7. Principles and techniques of biochemistry and molecular biology (2013) Keith Wilson, John Walker (Eds.), ( $7^{\text {th }}$ edn), Russia.

8. Sharshov K, Sivay M, Liu D, Pantin-Jackwood M, Marchenko V, et al. (2014) Molecular characterization and philogenetics of a reassortanr H13N8 influenza vilus isolated from gulls in Mongolia. Virus Genes 49(2): 237-249.

9. Kapustina OV (2016) Development and improvement of means and methods of control of especially dangerous infections caused by viruses of the order of Mononegavirales: Diss kand vet Sciences pp. 306.

10. World Health Organization (2005) posting date. WHO recommendations on the use of rapid diagnosis testing for influenza. World Health Organization, Geneva, Switzerland.

11. Leland DS, Ginocchio CC (2007) Role of cell culture for virus detection in the age of technology. Clin Microbiol Rev 20: 49-78.

12. Zavatonni M, Percivalle E, Cattaneo E, Ravello MG, Torsellini M, et al. (2003) Optimized detection of respiratory viruses in nasopharyngeal secretions. New Microbiol 26:133-140.

13. Bai GR, Sakoda Y, Mweene AS, Fujii N, Minakawa H, et al. (2006) Improvement of a rapid diagnosis kit to detect either influenza A or B virus infections. J Vet Med Sci 68: 35-40.

14. Alexander DJ (2000) A review of avian influenza in different bird species. Vet Microbiol 74(1-2): 3-13.

15. Gavin PJ, Thomson RB (2003) Review of rapid diagnostic tests for influenza. Clin Appl Immunol Rev 4: 151-172.

16. Uykei TM (2003) Influenza diagnosis and treatment in children: a re-

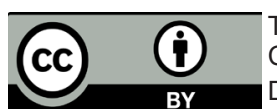

This work is licensed under Creative

Commons Attribution 4.0 License

DOI: 10.19080/JDVS.2019.09.555766 view of studies on clinically useful tests and antiviral treatment of influenza. Pediatr. Infect Dis J 22: 164-177.

17. Fedorko DP, Nelson NA, McAuliffe JM (2006) Subbarao K. Performance of rapid tests for detection of avian influenza A virus types H5N1 and H9N2. J Clin Microbiol 44: 1596-1597.

18. Mukhina AA, Shipulin GA, Kozhevnikova EN, Gorelov AV, Obukhov IL (2003) PCR Diagnostics of respiratory viral infections. Epidemiology and infectious diseases. 6: 51-55.

19. Kovalyuk NV, Satsuk VF, Machul'skaya EV (2007) Modern methods of diagnosis of bovine leukemia. Veterinary of Kuban.

20. Ishiguro T, Saitoh J, Yawata H, Yamagishi H, Iwasaki S et al. (1995) Homogeneous quantitative assay of hepatitis $\mathrm{C}$ virus RNA by polymerase chain reaction in the presence of a fluorescent intercalater. Anal Biochem 229: 207-213.

21. Morrison TM, Weis JJ, Wittwer CT (1998) Quantification of low-copy transcripts by continuous SYBR green I am monitoring during amplification. Biotechniques. 24: 954-962.

22. Osińska E, Golke A, Słońska A, Cymerys J, Bańbura MW, et al. (2012) HybProbes-based real-time PCR assay for rapid detection of equine herpesvirus type 2 DNA. Pol J Vet Sci 15(3): 411-416.

23. Xu R, Falardeau J, Avis TJ, Tambong JT (2016) HybProbes-based real-time PCR assay for specific identification of Streptomyces scabies and Streptomyces europaeiscabiei, the potato common scab pathogens. Lett Appl Microbiol 62(2): 153-159.

24. Tyagi S, Kramer FR (1996) Molecular beacons: probes that fluoresce upon hybridization. Nat Biotechnol 14: 303-308.

25. James AM, Baker MB, Bao G, Searles CD (2017) MicroRNA Detection Using a Double Molecular Beacon Approach: Distinguishing Between miRNA and Pre-miRNA. Theranostics 7(3): 634-646.

26. Holland PM, Abramson RD, Watson R, Gelfand DH (1991) Detection of specific polymerase chain reaction product by utilizing the $5^{\prime}-3^{\prime}$ exonuclease activity of Thermus aquaticus. Proc Natl Acad Sci USA, 88: 7276-7280.

27. Peng X, Nguyen A, Ghosh D (2018) Quantification of M13 and T7 bacteriophages by TaqMan and SYBR green qPCR. J Virol Methods. 252: 100-107.

28. Perez LE, Merrill GA, DeLorenzo RA, Schoenfeld TW, Vats A, et al. (2013) Evaluation of the specificity and sensitivity of a potential rapid influenza screening system. Diagn Microbiol Infect Dis 75(1): 77-80.

29. Ilinykh PA, Shestopalova EM, Khripko YI, Durimanov AG, Sharshov KA, et al. (2010) Detection of Influenza A virus RNA in birds by optimized real-time PCR system. Asian Pacific Journal of Tropical Medicine 3(5): 337- 340 .

Your next submission with Juniper Publishers
will reach you the below assets
- Quality Editorial service
- Swift Peer Review
- Reprints availability
- E-prints Service
- Manuscript Podcast for convenient understanding
- Global attainment for your research
- Manuscript accessibility in different formats
( Pdf, E-pub, Full Text, Audio)
- Unceasing customer service
Track the below URL for one-step submission
https://juniperpublishers.com/online-submission.php

